\title{
XI. On the dying struggle of the Dichotomous System
}

\section{W.S. MacLeay Esq. M.A. F.L.S.}

To cite this article: W.S. MacLeay Esq. M.A. F.L.S. (1830) XI. On the dying struggle of the Dichotomous System , Philosophical Magazine Series 2, 8:43, 53-57, DOI: $10.1080 / 14786443008675360$

To link to this article: http://dx.doi.org/10.1080/14786443008675360

册 Published online: 13 Jul 2009.

Submit your article to this journal $[\pi$

Џ Article views: 2

Q View related articles $\asymp$ 
"Philosophy of Zoology," and more recently in "British Animals," respecting the value of the dichotomous or binary method in natural history. With regard to the opinions advanced in the Quarterly Review, I presume that the Editor and his coadjutor are fully qualified to defend themselves, or rather that they are disposed to smile at the harmless abuse which Mr. MacLeay has thought proper to send forth against them. They are accustomed to witness the "dying struggles" of harpooned whales. It is indeed their pastime. I am, \&c.

Manse of Flisk, June 10, 1830.

John Fleming.

XI. On the Dying Struggle of the Dichotomous System. By W. S. MacLeaY, Esq. M.A. F.L.S. In a Letter to N.A. VIGORs, Esq. F.R.S.

[Continued from p. 445.]

[Upon the reconsideration of this article, we cannot but regret, in common with many others who take interest in the discussion, that so much personality should have been introduced into a scientific controversy; and $\mathrm{Mr}$. MacLeay's paper having been printed entire for private circulation, we have, in acquiescence with the general opinion, omitted, in the continuation which follows, and which will be concluded in the next number, many paragraphs, \&c., irrelevant to the subjects discussed. The portions of the paper; therefore, which our readers have now to peruse, must be considered as consisting only of a series of connected extracts from the original; containing, however, all the arguments advanced respecting the Dichotomous System. Our opinion of the unfairness of the article in the Quarterly Review, had been expressed (See Phil. Mag. and Annals, N.S. vol. vii. p. 379.) before Mr. Macleay's paper had been received; but what authority our much esteemed friend has for ascribing it to Dr. Fleming, is wholly unknown to us. Articles in favour of the Dichotomous System have repeatedly appeared in our pages *.-EDITors.]

I DO not know that Dr. Fleming has ever enlightened the world on the construction or anatomy of any one single animal: all he has published of value he has gathered from books. Now that any man, aware as he must be that the little acquaintance he possesses with Natural History he owes entirely to a perusal of the works of Linnæus, Jussieu, and Cuvier, should not have the modesty to distrust himself when differing from them on so essential a point as unity of plan in thecreation, is most astonishing. But what shall we say to

- See Phil. Mag. vol. Ixii. p. 200, 274; vol. lxv. p. 105, 183, 372, 428; vol. lxvi. p. 172. 
a writer that denies the existence of a single natural method? No, says he, I must admit that there are as many natural methods as there are organs. But where there are an infinite number of methods to effect a given object, such as the creation, it is clear that there can be no fixed plan. If the architect of the kirk of Flisk has in its composition huddled Grecian and Gothic, Saracen and Scotch, with every other order of architecture together, it is clear he had no plan, and our worthy minister preaches in the midst of confusion. So also, if the minister of the said kirk be right, must the creation be a mass of confusion, without any fixed plan on the part of the Creator? And yet he ventures to sneer at one of the most distinguished of naturalists, and to cite the following lines with respect to him:

" But Reason still, unless divinely taught,

Whate'er she learn, learns nothing as she ought."

He talks of demonstrating that there is no fixed plan in the creation. But how does he do this? Because, forsooth, the locomotive extremities of the horse and cow are represented by hands in man, fins in the whale, and wings in bats and squirrels; because, moreover, teeth may be incisors in one animal and molars in another, and so on!-therefore, animals are susceptible of one natural distribution according to their locomotive organs, and of others according to their teeth, \&c. To return to the kirk: Supposing it to be built on the most harmonious and uniform plan of Grecian architecture, and to be another Parthenon, Dr. Fleming may dichotomize it into architraves and not architraves, columns and not columns, friezes and not friezes, or any positives and negatives he pleases:-but will he tell us that, because he chooses so to divide it, therefore the architect had not one plan for the fabric, but as many plans as there are terms in architecture? Yet such is the reasoning by which he conceives himself forced to admit that the Deity had no plan in the creation. Sorry for it, very sorry he is; but he assures us there is no remedy.

But he says, "If unity of method in the creation be admitted, it will in many cases separate groups from other genera with which they are intimately connected;" and he proves this, by the genus Lepus in Zoology and Sambucus in Botany, as follows: "The hare; in relation to her offspring; exhibits an affinity with the horse and sheep; while the rabbit, in the same relation, claims kindred (as does also the cat) with the opossum and kangaroo." Ergo, a natural dichotomous division, according to Dr. Fleming, is into those that at their birth have their eyes open, containing the natural group the hare, the horse, 
and the sheep; and those which have them shut, such as another natural group comprising the rabbit, the cat, the opossum, and the kangaroo!

'The Doctor's botany is on a par with his zoology ; for says he, "In any arrangement which contemplated plants according as their stems were capable of producing flowers and fruit during many years, or able to produce flowers and fruit once only, (and the distinction is an important one, these two species, the dwarf and the common elder, would have belonged to different genera and even different orders." This system of vegetables now proposed by Dr. Fleming, is not quite new. I have before heard of plants annual, biennial, perennial, and everlastings. The credit he deserves, however, is the original consideration of it as a natural method of distribution. A similar system depending on their duration must, without doubt, be equally natural for animals, and he will, perhaps, soon publish, with his usual learning, names for the dichotomous subdivision of Animals immortal, and of Animals not immortal, in the first of which groups he places himself.

In like manner our botanist would naturally class one species of willow with arrow-root, because it is monandrous, and another with the ladies'-slipper, because it is diandrous. All methods are equally good, all divisions are the same, and he is there ready with his pen to favour all alike with crack-jaw names. But enough, and more than enough, of the above examples, which according to him prove that there is necessarily a rupture of affinities, "when we restrict a genus or species to a single place in our physiological system." If the reader does not think it proved, the Doctor asserts that it is, and that is quite sufficient.

Dr. Fleming has been, I have already said, so far acute as to perceive that in order to make the dichotomous division of nature go down, it was certainly necessary in the first place to deny all unity of plan in the creation. So also was it absolutely necessary to attack the law of continuity, and to deny the Linnæan maxim, "Natura opifex rerum non facit saltus"; for certainly no method takes such prodigious leaps as the dichotomous, which may also be termed, par excellence, the leaping one. Dr. Fleming indeed admits that the law exists when the changes of bodies take place with respect to time and space, but says he, "Where is there even the shadow of proof that the most perfect of created beings must previously have gone through all the progressive steps of advancement, or that among created beings there is such a gradual transition from one kind to another as to render it impossible for man to pronounce where the one ends and the other 
other begins?" Now Lamarck never made the first assertion as above stated, nor have I ever made the second; and yet both of us acknowledge the law of continuity in natural history.

In the Horce Entomologica I state that " Lamarck had unfortunately from a ready perception of affinities been induced to confound natural order, by which is meant the actual regularity of disposition which exists in nature, with that order of formation, by which is meant the process of it in time," and had thus fallen on that system of progressive development which Dr. Fleming now thinks he has so wittily caricatured. Indeed every naturalist who has had any perception of affinities bestowed on him by nature as among created beings, observed a regularity of disposition and a gradual transition from one kind to the other, which, although not such as the Doctor above describes it, is nevertheless certain. No orre indeed can doubt the fact. Let Dr. Fleming visit any great museum in Paris or London, let him for once in his life take the scalpel in hand, let him study such books as the Philosophie Anctomique, and he will soon be sensible how ignorant he has been of natural history; that is, if there be not some natural imperfection that prevents him from detecting affinities.

True it is, that chasms occur; but now, thanks to our collectors, those chasms are comparatively trifling, and moreover are every day filling up. As to their being many, it may appear paradoxical to the Doctor, but I wish to see infinitely more of them. If indeed those that exist should never be filled up by the exertions of collectors, we may still safely attribute them either to that extinction of species which has manifestly been produced by the ancient revolutions to which the surface of this globe has been at various times exposed, or to that extinction which has been produced by the hand of man. Geology, however, according to our anthor, is opposed to such bold ideas. Why? " Because the strata present to the student the relics of various groups of organized beings,"a most convincing argument truly ; and, secondly, "Because the fossils of the chalk rocks must not be mingled with those of the carboniferous limestone, nor with the species which now exist. All these must be studied as separate systems"! That is, the shell of a chalk rock is not a shell if it occurs in carboniferous limestone, and still something else if it occurs in Flisk.

"Greatly to our annoyance," says the Doctor, " nature occasionally makes a halt - as when she refused retractile claws to the hunting-tiger"! So that he does not merely lay down "first principles of arrangement founded on abstract 
reasoning," but, attempts to support them by examples. Let such men but have the heedlessness to pin themselves down by an example, and the utter futility of their reasoning is manifest at once. He cites the chittah for a want that only proves how the genus Felis passes off to the Canine tribe. And this he calls a balt! So also he says, "Nature indulges in frolicsome leaps, as in passing from the vertebral to the invertebral animals, and completes the confusion of those who wish to train her, by bolting off the course to convey man to his rational throne." The frolicsome leap from vertebral to invertebral animals I shall hereafter show to be grounded on ignorance of zoology. I shall merely now ask any person, whether naturalist or not. Does nature really bolt off her course in conveying man to the throne of reason? It may be indeed that her paces are not always equal - that $I$ believe to be truly the case; but nevertheless she remains steadily on the course, and if she has put man on the throne, she has also placed a series of animals on the steps that lead up to it. Some persons indeed have doubted, whether those steps on which she has placed the ourang-outang and some savage tribes of man, ought upon the whole to be considered the widest apart; and were it not that man possesses the gift of speech, they would so doubt with reason. There is no occasion, therefore, "to hope for the discovery of a semirational species to fill up the greatest gap that exists."

But, after all, this has really little to do with our present subject, unless Dr. Fleming be a materialist. We are now discussing the forms of matter, and unless Dr. F. thinks that mind is matter, he has no business to bring his reason upon the carpet. In their corporeal structure the ourangoutang and negro differ but little-it is degrading to think how little. It has however pleased the Deity to distinguish man by adding to his body a conscious immaterial being, endowed with a degree of free agency sufficient to render it morally responsible to its Creator. Bou

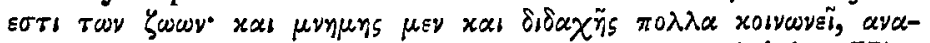

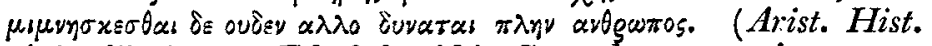
Anim. lib. i. c. 1. Ed. Schneid.) Secondary operative causes are no doubt constructed, like forms of matter, also on a wise plan; but if Dr. Fleming wishes to form a Dichotomous System of them, I fear he must patiently wait for his departure from a world which has furnished us only with senses capable of distinguishing the various forms of matter.

[To be continued.] 